\title{
An Insight on Small Molecule Induced Foot-Print Free Naive Pluripotent Stem Cells in Livestock
}

\author{
Mengmei Li ${ }^{*}$, Lanyu Li ${ }^{1,2 *}$, Jun Zhang1,2, Vinod Verma ${ }^{3}$, Qingyou Liu1,2, \\ Deshun Shi',2\#, Ben Huang ${ }^{1,2 \#}$ \\ ${ }^{1}$ School of Animal Science and Technology, Guangxi University, Nanning, China \\ ${ }^{2}$ State Key Laboratory for Conservation and Utilization of Subtropical Agro-Bioresources, Guangxi \\ University, Nanning, China \\ ${ }^{3}$ Centre of Biotechnology, Nehru Science Centre, University of Allahabad, Allahabad, India \\ Email: "eshunshi@gxu.edu.cn, " arihuangben@yahoo.com
}

Received 29 October 2014; revised 27 November 2014; accepted 18 December 2014

Copyright (C) 2015 by authors and Scientific Research Publishing Inc.

This work is licensed under the Creative Commons Attribution International License (CC BY).

http://creativecommons.org/licenses/by/4.0/

c) (i) Open Access

\begin{abstract}
Bona fide embryonic stem cell (ESC) lines from livestock species have been challenging to derive and maintain, contrasting mouse and human ESCs. However, induced pluripotent stem cells (iPSC) generated by reprogramming somatic cells tender an option, as they display characteristic features of ESC. The comprehension that induced pluripotent stem cells (iPSC) could be created with in no time also holds the potential of allowing pluripotent cells to be derived from animal models vital in biomedical research. Endeavors to produce bona fide pluripotent stem cells (PSC) from livestock have been going on for more than two decades. But, attempts to derive bona fide livestock iPS cells have met with limited success. Recently it's been reported that small molecules can augment reprogramming efficiency and may be used to substitute few or all transcription factors used for reprogramming. It is assumed that the reprogramming factors are conserved among species, and this small molecule reprogramming approach will probably apply to livestock species as well. So this review will focus mainly on the accomplishments of small molecules on accelerating cell reprogramming and obtaining naive pluripotency, and raise a new insight on, exogenous genes free, livestock naive iPSC generation with a new bullet, small molecule.
\end{abstract}

\section{Keywords}

Small Molecule, Foot-Print Free, Naive Pluripotent Stem Cell, Livestock

\footnotetext{
*Those authors contributed to this article equivalently.

${ }^{\#}$ Corresponding authors.
}

How to cite this paper: Li, M.M., Li, L.Y., Zhang, J., Verma, V., Liu, Q.Y., Shi, D.S. and Huang, B. (2015) An Insight on Small Molecule Induced Foot-Print Free Naive Pluripotent Stem Cells in Livestock. Stem Cell Discovery, 5, 1-9. 


\section{Introduction}

Naive pluripotent stem cell is defined by possessing pluripotent characteristic, expressing pluripotency marker gene, three germ layers in vitro and in vivo differentiation, especially, capable of forming germ-line chimera [1]-[3]. Pluripotent stem cells combined with embryos and transgenic animal technology, produced biomedical models, promoted animal breeding, genetic improvement of animal nature, and speed up the animal population genetic variation. And also it could break down the species barrier and kinship restrictions, overcome interspecific reproductive barriers, and acquire new traits which could not be obtained by traditional breeding methods. In addition, at the cellular level of embryos for early selection, it could improve the accuracy of selection, and shorten the breeding time [4]. Since livestock naive pluripotent stem cells had such important application prospects, in the past three decades, the researchers had been engaged in isolation and culture of those pluripotent stem cell, but were not fully successful [5] determined by not being able to capture naive fully pluripotent stage from embryos. With the advent of the induced pluripotent stem cells (iPSC) technology, by conducting some transcription factors into somatic cell, it could reactivate endogenous pluripotent related genes expression, and then transform somatic cell to pluripotent cell. Through this approach, in livestock, the pig, sheep, goat, cattle, horse, and buffalo iPSC had been reported [6]-[11]; it holds great potential to successfully capture naive stage fully pluripotency in livestock. However, livestock iPSC technology platform still has two major barriers: 1) it had not achieved naive fully pluripotent iPSC. Almost all of the reported livestock iPSC were not capable to form germ line chimera [10] which is the gold standard assay for pluripotency, except one report where porcine iPSC were capable of forming the germ line chimera, though efficiency was low [12]; 2) the integration of exogenous genes into the genome or not completely silent, might lead to carcinogenicity and oncogenes such as cmyc sustained expression that has potential to hamper downstream applications. Researcher has shown that iPSC with non-silenced exogenous gene significantly reduced the developmental capability of nuclear transfer embryos if used as a donor cell [13].

\section{Induced Pluripotent Stem Cells (iPSC) Generation}

Generation of a pluripotent state was only possible in case of cell fusion and somatic cell nuclear transfer [14] [15] until discovery of induced pluripotency by Yamanaka at 2006. Four factors [Pou5f1, Sox2, Klf4 and C-myc] selected from 24 prospective genes known to play a role in pluripotency maintenance were capable of initiating an ESC-like state when transduced into somatic cells [16]. In 2012 Yamanaka won the Nobel Prize in physiology or medicine for his finding of how to transform ordinary somatic cell into cells that, like embryonic stem cells, have potential of developing into any cell in the human body. Until now iPSC had been generated from many species, such as the human, rat, rabbit, pig, sheep, goats, cattle, horse, and buffalo etc [6]-[11] [17]-[19]. In recent years iPSC technology has become an important tool in the field of advanced biotechnology. This technique can be used in drug screening, cell therapy and organ transplantation, disease models [20] [21], animal breeding and transgenic animal production [22], therefore the iPSC technology since the debut were pursued by scientists all over the world.

\section{Methods for iPSC Generation}

Yamanaka [16] developed iPSC technology in 2006. Since then, based on this or modified protocol, researchers from various labs generated iPSC from different species. In humans by ectopic expression of transcription factors like, POU5F1, SOX2, KLF4 and C-MYC [17], or SOX2, POU5F1, NANOG and LIN28, researchers successfully transformed human fibroblast cells into iPS cells [23]. Further, experimentation with cellular reprogramming has demonstrated that the only indispensible factors are POU5F1 and SOX2 [24]. However, use of NANOG, LIN28, C-MYC and KLF-4 greatly increased reprogramming efficiency. Since, the inception of iPSC technology, one parameter that remains constant is stimulation of pluripotent related endogenous gene expression [SOX2, NANOG, LIN28, POU5F1, KLF4 and C-MYC etc.] in order to reprogram somatic cell regardless of approaches. There are various methods to reprogram somatic cell and these can be categorized broadly into two categories: viral vector and non-viral vector methods.

\subsection{Viral Vector Methods}

Viral vector methods mainly include lentiviral and retrovirus vector method. Retroviral vectors were commonly 
used in previous research for iPSC generation, mainly used to infect actively dividing cells, but not non-dividing cells such as neurons [16]. The lentiviral vector could effectively infect dividing cells and non-dividing cells, and it was the most conventional approach to generate iPSC. The biggest advantage of viral vector method was relatively high transfection efficiency, which was effectively delivering exogenous genes into the cells. However, this method may cause the viral vector sequence and exogenous transcriptional factor sequence permanently integrated into the cell genome, and may cause the insertion mutagenesis, that might interfere with the normal iPSC function. Moreover, the expressions of residual exogenous factor even lead to the occurrence of cancer, which would be a potential safety problem. It severely limits the application of iPSC at basic research and clinical research. In order to avoid these problems, instead of the permanent integration, adenovirus vector was used to deliver exogenous gene by transient transcription to obtain iPS cells [25]. In this approach probability of viral integration into the host genome was less, but the reprogramming efficiency was poor.

\subsection{Non-Viral Vector Methods}

Clinical application of iPSC generated by viral approach is limited by the fact that most protocols modify the genome to effect cellular reprogramming which carries the risk of insertion mutagenesis. So, there is a need to switch to non-integrating, non-viral strategies to reprogram somatic cells. Plasmid transfection is most commonly used non-viral vector method. This method could reduce the insertion of exogenous gene into host gemone. However, the transfection efficiency was relatively low, and the exogenous gene might be integrated into the cell genome or not completely silent [7]. Currently, researchers are using microRNA (Micro ribonucleic acid) induction method for virus and integration free mouse and human iPSC generation. However, livestock pluripotent stem cell regulation mechanism is not clear which is causing difficulty to use this method for iPSC generation in livestock [26]. But, this method still could not completely avoid the potential side-effect of exogenous micro RNA to host genome or intrinsic gene transcripting network. Even these commonly used methods are plagued with host genome integration issues. So the development of non-viral, non-integrating induction method has become a new hot spot for iPSC research. Kim et al., 2009 reported that applied recombination protein could completely circumvent the problems related with iPSC generation [27], and they claimed that iPSC has been generated by only recombination proteins of OCT4, SOX2, KLF4 and CYMC. However, reprogramming efficiency in this method was very low, and since then there were not any reproducible report which indicates it has no applied value. Hou et al., 2013 results showed that mouse somatic cells could be induced into pluripotent stem cells by seven small molecular compounds [CiPSC] without any exogenous genes [28]. Using this transgene free approach, they demonstrated that CiPSC can be generated from mouse somatic cells with a frequency up to $0.2 \%$. Those mice CiPSC were at naive pluripotency stage recognized by contribution to germ line transmission. Furthermore, chimeric mice with germ line transmission generated from CiPSCs were $100 \%$ viable and healthy. The utilization of small molecule compounds instead of exogenous gene is an ideal method to generate exogenous gene free and naive iPSC.

\section{The Prospect of Livestock, Exogenous Gene Free, Naive Induced Pluripotent Stem Cells: Small Molecule Compounds}

\subsection{Small Molecule Compounds Promoted iPSC Reprogramming}

At present, research results showed that small molecular compounds have a wide range of applications and significant effect to facilitate the study of iPSC reprogramming and related mechanism [2] [29] [30]. Through the screening of small molecule compounds, biological characteristics, cell fate, related signal pathway and its regulation mechanism of pluripotent stem cell could be clearly investigated and consequently obtaining fully pluripotent stem cells [30] [31]. Effects of small molecules on iPSC programming mainly have two aspects: promoting the efficiency of fully reprogrammed cells and replacing transcription factor [29] [31].

According to the functional mechanism of small molecule compounds on iPSC, they could be divided into two main categories: 1) acting on the protein kinase of signalling pathway to manipulate related gene expression; 2) altering epigenetic landscape by directly affecting histone methylation, acetylation, and phosphorylation [31]. Small molecule compounds could significantly improve somatic cell reprogramming efficiency which has been verified by various reports on iPSC generation from human, mouse, rat, cattle and other species. The ALK inhibitor SB431542, MEK1/2 inhibitor PD0325901 enhanced the efficiency of human cell reprogramming up to 
200 folds [32]. PD0325901 with Thiazovivin and SB431542 significantly increased reprogramming efficiency [79.5 - 200 times] in human fibroblasts transfected with four exogenous transcription factors [33] [34]. Moreover, it also has shown improvement in bovine somatic cell reprogramming [35]. Histone deacetylase inhibitors [VPA and Sodium butyrate], DNA methyltransferase inhibitors (5-azacytidine, RG108 and BayK8644) significantly improved mouse and human cell reprogramming efficiency up to 20 - 50 times [24] [36]-[38]. Xie Xin research group's [39] studies showed that the LiCl by increasing the expression of Nanog and change of cell epigenetic modification, significantly increased the mouse somatic cell reprogramming efficiency up to 60 times. At 2013, they also found that the use of inhibitors of P53 could improve the cell reprogramming effective [40]. Current research results proposed that small molecule compound [CYT296] induced chromatin de-condensation and facilitated induced pluripotent stem cell generation. This novel small molecule could increase OSKM-mediated iPSC induction more than 10 folds [41].

\subsection{Small Molecule Compounds Replaced Transcription Factors for Reprogramming, and Contributed to Exogenous Gene Free iPSC}

Currently, large number of studies have indicated that small molecule compounds can substitute related transcription factors for cell reprogramming, such as E-616452, LY-364947 inhibitors could replace transcription factor Sox2 on mouse fibroblasts reprogramming [42] [43]. Mouse fibroblast cells transfected with Oct4, Sox2, c-Myc with the synergistic effects of Kenpaullone could be fully reprogrammed into iPS cells, showed that Kenpaullone substituted Klf4 reprogramming function [44]. The Melton's team [45] by adding VPA converted somatic cell transfected with only two factors Oct4 and Sox2 into iPSC, which eliminates the requirement of oncogene c-Myc and Klf4 for iPSC generation. Ding's team [36] also found that iPSC could be generated by ectopic expression of only two transcription factors i.e., Oct4 and Klf4, along with small molecules BIX-01294 and BayK8644. Also Sui et al., 2014 found that using small molecule trimethoprim [TMP] by engineering reprogramming factors to a destabilizing protein domain, they achieved inducible generation of mouse and pig iPSCs without exogenous OCT4 or KLF4 transduction [46]. Research further proved that using only one transcription factor, OCT4, combined with some small molecule compounds [valproic acid, CHIR99021, 616452, tranylcypromine] successfully reprogrammed mouse and human somatic cells into pluripotent stem cells [37] [47] [48]. Recently, Deng Hongkui research group's finding showed that mouse somatic cells could be induced into naive pluripotent stem cells with small molecular compounds [CiPSC], without any exogenous gene application [28]. All these findings indicates that chemical induction approach holds the great potential for generating exogenous genes free iPSC from other species including livestock. However, until now, no progress has been made in livestock species similar to the reports as that of Hou et al., 2013. Kang et al., 2014 demonstrated that combinations of small molecules (oxysterol and purmorphamine) could compensate for all reprogramming factors and were sufficient to directly reprogram mouse somatic cells into naive-like iPSC as determined by nongerm line chimera forming ability [49]. We also screened small molecular compounds to establish our own induction system. Currently, our results showed that we had obtained mouse and goat CiPSC-like cells. Those cells formed 3D colonies with clear edge, and expressed certain pluripotentcy-related genes. Moreover, they also expressed three germ layer related marker genes while they were differentiated in vitro (2014, unpublished results). Partially, we have proved that iPSC could be generated by fully chemical approach without any exogenous gene. However, more experiments need to be done to determine whether those CiPSC-like cells were fully pluripotent. The above studies exploring the use of small molecule compounds on iPSC provided theoretical and technical basis to achieve exogenous gene free livestock naive iPSC.

\subsection{Small Molecule Compounds Maintained Pluripotent Stem Cell Self-Renewal and Conversed Primed to Naive Stage}

Ying et al. reported that chemically defined medium supplemented with small molecule compounds [PD0325901 and CHIR99021] and LIF, named 2i/LIF medium [50] could support not only established mouse and human pluripotent stem cells lines [51]-[53], but also pluripotent stem cell from other species, such as rats and mice of other strains, which were not able to survive and sustain in the traditional culture system. 3i/LIF culture medium including three inhibitors, CHIR99021, PD184352, and SU5402, led to the first isolation and establishment of bona fide ESCs from rat embryos [54] [55]. Eventually, small molecules helped the researchers to capture naive pluripotent stem cell lines [56] [57]. The small molecule PD0325901 inhibitor blocks the ERK phosphorylation 
in order to maintain undifferentiated state [22] [58] [59], and at the same time, another small molecule CHIR99021 inhibits GSK3 activity, which facilitates the Wnt signaling pathway and it results in pluripotent stem cell selfrenewal. Therefore, $2 \mathrm{i} / \mathrm{LIF}$ promotes the self-renewal and maintains the pluripotency of stem cells. Adding other small molecular compounds [PD173074 and A-83-01] into 2i/LIF could convert primed stage pluripotent cells [mouse epiblast stem cell] to naive stage fully pluripotent stem cell [60]. Sodium butyrate efficiently converted fully reprogrammed [Naive] induced pluripotent stem cells from mouse partially reprogrammed [Primed] cells [61]. Using small molecule SB431542 [TGF-inhibitor] instead of CHIR99021 in 2i/LIF medium, significantly improves the efficiency of mouse embryonic stem cells generation from embryo [up to 100\%], and also facilitates the retrieval of embryonic stem cell [ES] lines from other mouse strains which have not been established [62]. The recent studies [2] have showed that morphological and biological characteristics of human ES was more similar to the mouse primed epiblast stem cells [counterpart to primed state]. In order to obtain naive stage of human pluripotent stem cell similar to that of mouse ES cell, they used 2i/LIF culture system supplemented with other small molecules to culture human ES cell, and found that morphology of their colony turned into dome shape as similar as that of mouse ES from tiled monolayer cells. When naive human ES were injected into mouse embryo, germ-line transmission chimera mouse could be produced [2]. The outcome of the experiment proved that small molecule compounds could convert the stem cell from primed to naive state. The above research results showed that small molecule compounds were capable to effectively promote the pluripotent stem cell self-renewal and transformation from primed to naive pluripotency. It has opened a door for application of small molecule compounds on livestock pluripotent stem cells in order to achieve naive pluripotency.

\subsection{Small Molecule Compounds Supported Livestock Pluripotent Stem Cell in Vitro Culture}

In the past 3 years, researcher attempted to use small molecule compounds for livestock pluripotent stem cells generation and culture, and there has been some progress. Nagy supplemented culture with several small molecular compounds [A83-01, Thiazovivin and SB431542] and transfected the horse fibroblast cells with reprogramming transcription factors. They were able to obtained horse iPSC cell lines for the first time, but did not confirmed whether the cells were fully pluripotent, naive stage [8]. Several reports suggested that small molecule inhibitors could be used in iPSC culture to increase the homogeneity, especially, pig iPSC [63]. Rodriguez [2012], Zhang [2014] and Gao [2014], respectively, showed that using 2i/LIF medium would promote access to fully pluripotent porcine naive iPSC and its self-renewal [63]-[65]. Sharma showed that adding small molecular compounds Y-27632 or SU5402 into culture could promote the colony formation and maintain long-term culture of buffalo ES-like cell. However, he did not obtain chimeric buffalo [66]-[68]. In recent years, our results also showed that 2i/LIF medium had potential application prospect on bovine and other livestock pluripotent stem cells [ES/iPSC] [7] [69] [70]. Our latest research results [71] shows that the use of GSK inhibitors in small molecule compounds CHIR and BIO would improve the buffalo ES-like cell colony formation rate and the proliferation potential. Therefore, through the further screening, some small molecule compounds are expected to be discovered to increase livestock iPSC reprogramming efficiency, replace all transcription factors and capture fully pluripotentcy in vitro, subsequently, exogenous gene free livestock naive iPSC will be obtained.

\section{Conclusion}

Naive pluripotent stem cells from ungulates could be used for the production of biomedical models and it will help in accelerating animal breeding. Still we do not have those naive state pluripotent stem cells but are much closer than ever before. Above all, a new bullet, small molecule compounds will be able to break through barriers by promoting iPSC reprogramming efficiency and self-renewal, converting primed to naive stage pluripotentcy, generating exogenous gene free chemically induced pluripotent stem cell from livestock. It is foreseeable that the interplay between iPSC technology and small molecule compounds will push forward the application of livestock iPSC-based biomedical model and animal breeding. At next step, research should be focused on analyzing the naive pluripotent stem cell related signaling pathway for maintaining pluripotency and converting primed to naive stage, then establishing a small molecule screening library. Subsequently, using high-throughput screening platform, small molecule compounds which could capture naive pluripotent stem cell in livestock will be selected. After procuring those selected small molecule compounds, we will be able to cross the barriers to achieve exogenous gene free naive pluripotent stem cell from livestock. 


\section{Acknowledgements}

This research was supported by the grants from the Scientific Research Foundation of Guangxi University [Grant No. XGZ130880], Guangxi Natural Science Foundation [Grant No. 2014GXNSFCB118003], and Chinese National Natural Science Foundation [Grant No. 31401267].

\section{References}

[1] Nichols, J. and Smith, A. (2009) Naive and Primed Pluripotent States. Cell Stem Cell, 4, 487-492. http://dx.doi.org/10.1016/j.stem.2009.05.015

[2] Gafni, O., Weinberger, L., Mansour, A.A., Manor, Y.S., Chomsky, E., Ben-Yosef, D., et al. (2013) Derivation of Novel Human Ground State Naive Pluripotent Stem Cells. Nature, 504, 282-286. http://dx.doi.org/10.1038/nature12745

[3] Hassani, S.N., Totonchi, M., Gourabi, H., Scholer, H.R. and Baharvand, H. (2014) Signaling Roadmap Modulating Naive and Primed Pluripotency. Stem Cells and Development, 23, 193-208. http://dx.doi.org/10.1089/scd.2013.0368

[4] Nowak-Imialek, M. and Niemann, H. (2013) Pluripotent Cells in Farm Animals: State of the Art and Future Perspectives. Reproduction Fertility and Development, 25, 103-128. http://dx.doi.org/10.1071/RD12265

[5] Zhao, Y., Lin, J., Wang, L., Chen, B., Zhou, C., Chen, T., et al. (2011) Derivation and Characterization of Ovine Embryonic Stem-Like Cell Lines in Semi-Defined Medium without Feeder Cells. Journal of Experimental Zoology Part A, Ecological Genetics and Physiology, 315, 639-648. http://dx.doi.org/10.1002/jez.715

[6] Liao, J., Cui, C., Chen, S., Ren, J., Chen, J., Gao, Y., et al. (2009) Generation of Induced Pluripotent Stem Cell Lines from Adult Rat Cells. Cell Stem Cell, 4, 11-15. http://dx.doi.org/10.1016/j.stem.2008.11.013

[7] Huang, B., Li, T., Alonso-Gonzalez, L., Gorre, R., Keatley, S., Green, A., et al. (2011) A Virus-Free Poly-Promoter Vector Induces Pluripotency in Quiescent Bovine Cells under Chemically Defined Conditions of Dual Kinase Inhibition. PLoS One, 6, e24501. http://dx.doi.org/10.1371/journal.pone.0024501

[8] Nagy, K., Sung, H.K., Zhang, P., Laflamme, S., Vincent, P., Agha-Mohammadi, S., et al. (2011) Induced Pluripotent Stem Cell Lines Derived from Equine Fibroblasts. Stem Cell Reviews, 7, 693-702. http://dx.doi.org/10.1007/s12015-011-9239-5

[9] Deng, Y., Liu, Q., Luo, C., Chen, S., Li, X., Wang, C., et al. (2012) Generation of Induced Pluripotent Stem Cells From Buffalo [Bubalus bubalis] Fetal Fibroblasts with Buffalo Defined Factors. Stem Cells and Development, 21, 2485-2494. http://dx.doi.org/10.1089/scd.2012.0018

[10] Liu, J., Balehosur, D., Murray, B., Kelly, J.M., Sumer, H. and Verma, P.J. (2012) Generation and Characterization of Reprogrammed Sheep Induced Pluripotent Stem Cells. Theriogenology, 77, 338-346. http://dx.doi.org/10.1016/j.theriogenology.2011.08.006

[11] Song, H., Li, H., Huang, M., Xu, D., Gu, C., Wang, Z., et al. (2013) Induced Pluripotent Stem Cells from Goat Fibroblasts. Molecular Reproduction and Development, 80, 1009-1017. http://dx.doi.org/10.1002/mrd.22266

[12] West, F.D., Uhl, E.W., Liu, Y., Stowe, H., Lu, Y., Yu, P., et al. (2011) Brief Report: Chimeric Pigs Produced from Induced Pluripotent Stem Cells Demonstrate Germline Transmission and No Evidence of Tumor Formation in Young Pigs. Stem Cells, 29, 1640-1643. http://dx.doi.org/10.1002/stem.713

[13] Fan, N., Chen, J., Shang, Z., Dou, H., Ji, G., Zou, Q., et al. (2013) Piglets Cloned from Induced Pluripotent Stem Cells. Cell Research, 23, 162-166. http://dx.doi.org/10.1038/cr.2012.176

[14] McLaren, A. (2000) Cloning: Pathways to a Pluripotent Future. Science, 288, 1775-1780. http://dx.doi.org/10.1126/science.288.5472.1775

[15] Do, J.T. and Scholer, H.R. (2004) Nuclei of Embryonic Stem Cells Reprogram Somatic Cells. Stem Cells, 22, $941-949$. http://dx.doi.org/10.1634/stemcells.22-6-941

[16] Takahashi, K. and Yamanaka, S. (2006) Induction of Pluripotent Stem Cells from Mouse Embryonic and Adult Fibroblast Cultures by Defined Factors. Cell, 126, 663-676. http://dx.doi.org/10.1016/j.cell.2006.07.024

[17] Takahashi, K., Tanabe, K., Ohnuki, M., Narita, M., Ichisaka, T., Tomoda, K., et al. (2007) Induction of Pluripotent Stem Cells from Adult Human Fibroblasts by Defined Factors. Cell, 131, 861-872. http://dx.doi.org/10.1016/j.cell.2007.11.019

[18] Hamanaka, S., Yamaguchi, T., Kobayashi, T., Kato-Itoh, M., Yamazaki, S., Sato, H., et al. (2011) Generation of Germline-Competent Rat Induced Pluripotent Stem Cells. PIOS One, 6, e22008. http://dx.doi.org/10.1371/journal.pone.0022008

[19] Osteil, P., Tapponnier, Y., Markossian, S., Godet, M., Schmaltz-Panneau, B., Jouneau, L., et al. (2013) Induced Pluripotent Stem Cells Derived from Rabbits Exhibit Some Characteristics of Naive Pluripotency. Biology Open, 2, 613- 
628. http://dx.doi.org/10.1242/bio.20134242

[20] Inoue, H., Nagata, N., Kurokawa, H. and Yamanaka, S. (2014) iPS Cells: A Game Changer for Future Medicine. The EMBO Journal, 33, 409-417. http://dx.doi.org/10.1002/embj.201387098

[21] Suh, J.H., Kim, D., Kim, H., Helfman, D.M., Choi, J.H., Lee, B.H., et al. (2014) Modeling of Menkes Disease via Human Induced Pluripotent Stem Cells. Biochemical and Biophysical Research Communications, 444, 311-318. http://dx.doi.org/10.1016/j.bbrc.2014.01.038

[22] Miao, X. (2013) Recent Advances in the Development of New Transgenic Animal Technology. Cellular and Molecular Life Sciences, 70, 815-828. http://dx.doi.org/10.1007/s00018-012-1081-7

[23] Yu, J., Vodyanik, M.A., Smuga-Otto, K., Antosiewicz-Bourget, J., Frane, J.L., Tian, S., et al. (2007) Induced Pluripotent Stem Cell Lines Derived from Human Somatic Cells. Science, 318, 1917-1920. http://dx.doi.org/10.1126/science.1151526

[24] Huangfu, D., Maehr, R., Guo, W., Eijkelenboom, A., Snitow, M., Chen, A.E., et al. (2008) Induction of Pluripotent Stem Cells by Defined Factors Is Greatly Improved by Small-Molecule Compounds. Nature biotechnology, 26, 795797. http://dx.doi.org/10.1038/nbt1418

[25] Stadtfeld, M., Nagaya, M., Utikal, J., Weir, G. and Hochedlinger, K. (2008) Induced Pluripotent Stem Cells Generated without Viral Integration. Science, 322, 945-949. http://dx.doi.org/10.1126/science.1162494

[26] Ma, K., Song, G., An, X., Fan, A., Tan, W., Tang, B., et al. (2014) miRNAs Promote Generation of Porcine-Induced Pluripotent Stem Cells. Molecular and Cellular Biochemistry, 389, 209-218 http://dx.doi.org/10.1007/s11010-013-1942-X

[27] Kim, D., Kim, C.H., Moon, J.I., Chung, Y.G., Chang, M.Y., Han, B.S., et al. (2009) Generation of Human Induced Pluripotent Stem Cells by Direct Delivery of Reprogramming Proteins. Cell Stem Cell, 4, 472-476. http://dx.doi.org/10.1016/j.stem.2009.05.005

[28] Hou, P., Li, Y., Zhang, X., Liu, C., Guan, J., Li, H., et al. (2013) Pluripotent Stem Cells Induced from Mouse Somatic Cells by Small-Molecule Compounds. Science, 341, 651-654. http://dx.doi.org/10.1126/science.1239278

[29] Su, J.B., Pei, D.Q. and Qin, B.M. (2013) Roles of Small Molecules in Somatic Cell Reprogramming. Acta Pharmacologica Sinica, 34, 719-724. http://dx.doi.org/10.1038/aps.2013.73

[30] Jung, D.W., Kim, W.H. and Williams, D.R. (2014) Reprogram or Reboot: Small Molecule Approaches for the Production of Induced Pluripotent Stem Cells and Direct Cell Reprogramming. ACS Chemical Biology, 9, 80-95. http://dx.doi.org/10.1021/cb400754f

[31] Li, W., Jiang, K., Wei, W., Shi, Y. and Ding, S. (2013) Chemical Approaches to Studying Stem Cell Biology. Cell Research, 23, 81-91. http://dx.doi.org/10.1038/cr.2012.182

[32] Li, W., Wei, W., Zhu, S., Zhu, J., Shi, Y., Lin, T., et al. (2009) Generation of Rat and Human Induced Pluripotent Stem Cells by Combining Genetic Reprogramming and Chemical Inhibitors. Cell Stem Cell, 4, 16-19. http://dx.doi.org/10.1016/j.stem.2008.11.014

[33] Lin, T., Ambasudhan, R., Yuan, X., Li, W., Hilcove, S., Abujarour, R., et al. (2009) A Chemical Platform for Improved Induction of Human iPSCs. Nature Methods, 6, 805-808. http://dx.doi.org/10.1038/nmeth.1393

[34] Gross, B., Sgodda, M., Rasche, M., Schambach, A., Gohring, G., Schlegelberger, B., et al. (2013) Improved Generation of Patient-Specific Induced Pluripotent Stem Cells Using a Chemically-Defined and Matrigel-Based Approach. Current Molecular Medicine, 13, 765-776. http://dx.doi.org/10.2174/1566524011313050008

[35] Grace, A., McMillan, M., Schmoelzl, S. and Hinch, G. (2013) 187 Increased Efficiency of Deriving Bovine Stem Cell-Like Colonies Using Valproic Acid and Small Molecule Cocktails. Reproduction, Fertility and Development, 26, 208. http://dx.doi.org/10.1071/RDv26n1Ab187

[36] Shi, Y., Desponts, C., Do, J.T., Hahm, H.S., Scholer, H.R. and Ding, S. (2008) Induction of Pluripotent Stem Cells from Mouse Embryonic Fibroblasts by Oct4 and Klf4 with Small-Molecule Compounds. Cell Stem Cell, 3, 568-774. http://dx.doi.org/10.1016/j.stem.2008.10.004

[37] Zhu, S., Li, W., Zhou, H., Wei, W., Ambasudhan, R., Lin, T., et al. (2010) Reprogramming of Human Primary Somatic Cells by OCT4 and Chemical Compounds. Cell Stem Cell, 7, 651-655. http://dx.doi.org/10.1016/j.stem.2010.11.015

[38] Trokovic, R., Weltner, J., Manninen, T., Mikkola, M., Lundin, K., Hamalainen, R., et al. (2013) Small Molecule Inhibitors Promote Efficient Generation of Induced Pluripotent Stem Cells from Human Skeletal Myoblasts. Stem Cells and Development, 22, 114-123. http://dx.doi.org/10.1089/scd.2012.0157

[39] Wang, Q., Xu, X., Li, J., Liu, J., Gu, H., Zhang, R., et al. (2011) Lithium, an Anti-Psychotic Drug, Greatly Enhances the Generation of Induced Pluripotent Stem Cells. Cell Research, 21, 1424-1435. http://dx.doi.org/10.1038/cr.2011.108

[40] Xu, X., Wang, Q., Long, Y., Zhang, R., Wei, X., Xing, M., et al. (2013) Stress-Mediated p38 Activation Promotes Somatic Cell Reprogramming. Cell Research, 23, 131-141. http://dx.doi.org/10.1038/cr.2012.143 
[41] Wei, X., Chen, Y., Xu, Y., Zhan, Y., Zhang, R., Wang, M., et al. (2014) Small Molecule Compound Induces Chromatin De-Condensation and Facilitates Induced Pluripotent Stem Cell Generation. Journal of Molecular Cell Biology, 6, 409-420. http://dx.doi.org/10.1093/jmcb/mju024

[42] Ichida, J.K., Blanchard, J., Lam, K., Son, E.Y., Chung, J.E., Egli, D., et al. (2009) A Small-Molecule Inhibitor of Tgf- $\beta$ Signaling Replaces Sox2 in Reprogramming by Inducing Nanog. Cell Stem Cell, 5, 491-503. http://dx.doi.org/10.1016/j.stem.2009.09.012

[43] Staerk, J., Lyssiotis, C.A., Medeiro, L.A., Bollong, M., Foreman, R.K., Zhu, S., et al. (2011) Pan-Src Family Kinase Inhibitors Replace Sox2 during the Direct Reprogramming of Somatic Cells. Angewandte Chemie International Edition, 50, 5734-5736. http://dx.doi.org/10.1002/anie.201101042

[44] Lyssiotis, C.A., Foreman, R.K., Staerk, J., Garcia, M., Mathur, D., Markoulaki, S., et al. (2009) Reprogramming of Murine Fibroblasts to Induced Pluripotent Stem Cells with Chemical Complementation of Klf4. Proceedings of the National Academy of Sciences, 106, 8912-8917. http://dx.doi.org/10.1073/pnas.0903860106

[45] Huangfu, D., Osafune, K., Maehr, R., Guo, W., Eijkelenboom, A., Chen, S., et al. (2008) Induction of Pluripotent Stem Cells from Primary Human Fibroblasts with Only Oct4 and Sox2. Nature Biotechnology, 26, 1269-1275. http://dx.doi.org/10.1038/nbt.1502

[46] Sui, D., Sun, Z., Xu, C., Wu, Y., Capecchi, M.R., Wu, S., et al. (2014) Fine-Tuning of iPSC Derivation by an Inducible Reprogramming System at the Protein Level. Stem Cell Reports, 2, 21-33. http://dx.doi.org/10.1016/j.stemcr.2014.03.013

[47] Li, Y., Zhang, Q., Yin, X., Yang, W., Du, Y., Hou, P., et al. (2011) Generation of iPSCs from Mouse Fibroblasts with a Single Gene, Oct4, and Small Molecules. Cell Research, 21, 196-204. http://dx.doi.org/10.1038/cr.2010.142

[48] Yuan, X., Wan, H., Zhao, X., Zhu, S., Zhou, Q. and Ding, S. (2011) Brief Report: Combined Chemical Treatment Enables Oct4-Induced Reprogramming from Mouse Embryonic Fibroblasts. Stem Cells, 29, 549-553. http://dx.doi.org/10.1002/stem.594

[49] Kang, P.J., Moon, J.H., Yoon, B.S., Hyeon, S., Jun, E.K., Park, G., et al. (2014) Reprogramming of Mouse Somatic Cells into Pluripotent Stem-Like Cells Using a Combination of Small Molecules. Biomaterials, 35, 336-345. http://dx.doi.org/10.1016/j.biomaterials.2014.05.015

[50] Ying, Q.L., Wray, J., Nichols, J., Batlle-Morera, L., Doble, B., Woodgett, J., et al. (2008) The Ground State of Embryonic Stem Cell Self-Renewal. Nature, 453, 519-523. http://dx.doi.org/10.1038/nature06968

[51] Hirano, K., Nagata, S., Yamaguchi, S., Nakagawa, M., Okita, K., Kotera, H., et al. (2012) Human and Mouse Induced Pluripotent Stem Cells Are Differentially Reprogrammed in Response to Kinase Inhibitors. Stem Cells and Development, 21, 1287-1298. http://dx.doi.org/10.1089/scd.2011.0283

[52] Leitch, H.G., McEwen, K.R., Turp, A., Encheva, V., Carroll, T., Grabole, N., et al. (2013) Naive Pluripotency Is Associated with Global DNA Hypomethylation. Nature Structural \& Molecular Biology, 20, 311-316. http://dx.doi.org/10.1038/nsmb.2510

[53] Yamaji, M., Ueda, J., Hayashi, K., Ohta, H., Yabuta, Y., Kurimoto, K., et al. (2013) PRDM14 Ensures Naive Pluripotency through Dual Regulation of Signaling and Epigenetic Pathways in Mouse Embryonic Stem Cells. Cell Stem Cell, 12, 368-382. http://dx.doi.org/10.1016/j.stem.2012.12.012

[54] Buehr, M., Meek, S., Blair, K., Yang, J., Ure, J., Silva, J., et al. (2008) Capture of Authentic Embryonic Stem Cells from Rat Blastocysts. Cell, 135, 1287-1298. http://dx.doi.org/10.1016/j.cell.2008.12.007

[55] Li, P., Tong, C., Mehrian-Shai, R., Jia, L., Wu, N., Yan, Y., et al. (2008) Germline Competent Embryonic Stem Cells Derived from Rat Blastocysts. Cell, 135, 1299-1310. http://dx.doi.org/10.1016/j.cell.2008.12.006

[56] Leitch, H.G., Blair, K., Mansfield, W., Ayetey, H., Humphreys, P., Nichols, J., et al. (2010) Embryonic Germ Cells from Mice and Rats Exhibit Properties Consistent with a Generic Pluripotent Ground State. Development, 137, 22792287. http://dx.doi.org/10.1242/dev.050427

[57] Blair, K., Leitch, H.G., Mansfield, W., Dumeau, C.E., Humphreys, P. and Smith, A.G. (2012) Culture Parameters for Stable Expansion, Genetic Modification and Germline Transmission of Rat Pluripotent Stem Cells. Biology Open, 1, 58-65. http://dx.doi.org/10.1242/bio.2011029

[58] Ten Berge, D., Kurek, D., Blauwkamp, T., Koole, W., Maas, A., Eroglu, E., et al. (2011) Embryonic Stem Cells Require Wnt Proteins to Prevent Differentiation to Epiblast Stem Cells. Nature Cell Biology, 13, 1070-1075. http://dx.doi.org/10.1038/ncb2314

[59] Kinehara, M., Kawamura, S., Tateyama, D., Suga, M., Matsumura, H., Mimura, S., et al. (2013) Protein Kinase C Regulates Human Pluripotent Stem Cell Self-Renewal. PlOS One, 8, e54122. http://dx.doi.org/10.1371/journal.pone.0054122

[60] Zhou, H., Li, W., Zhu, S., Joo, J.Y, Do, J.T., Xiong, W., et al. (2010) Conversion of Mouse Epiblast Stem Cells to an Earlier Pluripotency State by Small Molecules. Journal of Biological Chemistry, 285, 29676-29680. 
http://dx.doi.org/10.1074/jbc.C110.150599

[61] Kang, S.J., Park, Y.I., So, B. and Kang, H.G. (2014) Sodium Butyrate Efficiently Converts Fully Reprogrammed Induced Pluripotent Stem Cells from Mouse Partially Reprogrammed Cells. Cellular Reprogramming, 16, 345-354. http://dx.doi.org/10.1089/cell.2013.0087

[62] Baharvand, H. and Hassani, S.N. (2013) A New Chemical Approach to the Efficient Generation of Mouse Embryonic Stem Cells. Methods in Molecular Biology, 997, 13-22. http://dx.doi.org/10.1007/978-1-62703-348-0_2

[63] Rodriguez, A., Allegrucci, C. and Alberio, R. (2012) Modulation of Pluripotency in the Porcine Embryo and iPS Cells. PLOS One, 7, e49079. http://dx.doi.org/10.1371/journal.pone.0049079

[64] Gao, Y., Guo, Y., Duan, A., Cheng, D., Zhang, S. and Wang, H. (2014) Optimization of Culture Conditions for Maintaining Porcine Induced Pluripotent Stem Cells. DNA and Cell Biology, 33, 1-11. http://dx.doi.org/10.1089/dna.2013.2095

[65] Zhang, Y., Wei, C., Zhang, P., Li, X., Liu, T., Pu, Y., et al. (2014) Efficient Reprogramming of Naive-Like Induced Pluripotent Stem Cells from Porcine Adipose-Derived Stem Cells with a Feeder-Independent and Serum-Free System. PLOS One, 9, e85089. http://dx.doi.org/10.1371/journal.pone.0085089

[66] Sharma, R., George, A., Kamble, N.M., Singh, K.P., Chauhan, M.S., Singla, S.K., et al. (2011) Optimization of Culture Conditions to Support Long-Term Self-Renewal of Buffalo (Bubalus bubalis) Embryonic Stem Cell-Like Cells. Cell Reprogramming, 13, 539-549.

[67] Sharma, R., George, A., Chauhan, M.S., Singla, S., Manik, R.S. and Palta, P. (2013) ROCK Inhibitor Y-27632 Enhances the Survivability of Dissociated Buffalo (Bubalus bubalis) Embryonic Stem Cell-Like Cells. Reproduction, Fertility and Development, 25, 446-455. http://dx.doi.org/10.1071/RD11315

[68] Sharma, R., Kamble, N.M., George, A., Chauhan, M.S., Singla, S., Manik, R.S., et al. (2013) Effect of TGF- $\beta 1$ Superfamily Members on Survival of Buffalo (Bubalus bubalis) Embryonic Stem-Like Cells. Reproduction in Domestic Animals, 48, 569-576. http://dx.doi.org/10.1111/rda.12126

[69] Harris, D., Huang, B. and Oback, B. (2013) Inhibition of MAP2K and GSK3 Signaling Promotes Bovine Blastocyst Development and Epiblast-Associated Expression of Pluripotency Factors. Biology of Reproduction, 88, 74. http://dx.doi.org/10.1095/biolreprod.112.103390

[70] Verma, V., Huang, B., Kallingappa, P.K. and Oback, B. (2013) Dual Kinase Inhibition Promotes Pluripotency in Finite Bovine Embryonic Cell Lines. Stem Cells and Development, 22, 1728-1742. http://dx.doi.org/10.1089/scd.2012.0481

[71] Lu, F., Lao, Y., Sun, H., Lei, C., Deng, Y., Luo, C., et al. (2013) 195 Effects of Gsk3 Inhibitor on the Pluripotency Maintenance of Buffalo Embryonic Stem-Cell-Like Cells. Reproduction, Fertility and Development, 26, 212. http://dx.doi.org/10.1071/RDv26n1Ab195 
Scientific Research Publishing (SCIRP) is one of the largest Open Access journal publishers. It is currently publishing more than 200 open access, online, peer-reviewed journals covering a wide range of academic disciplines. SCIRP serves the worldwide academic communities and contributes to the progress and application of science with its publication.

Other selected journals from SCIRP are listed as below. Submit your manuscript to us via either submit@scirp.org or Online Submission Portal.
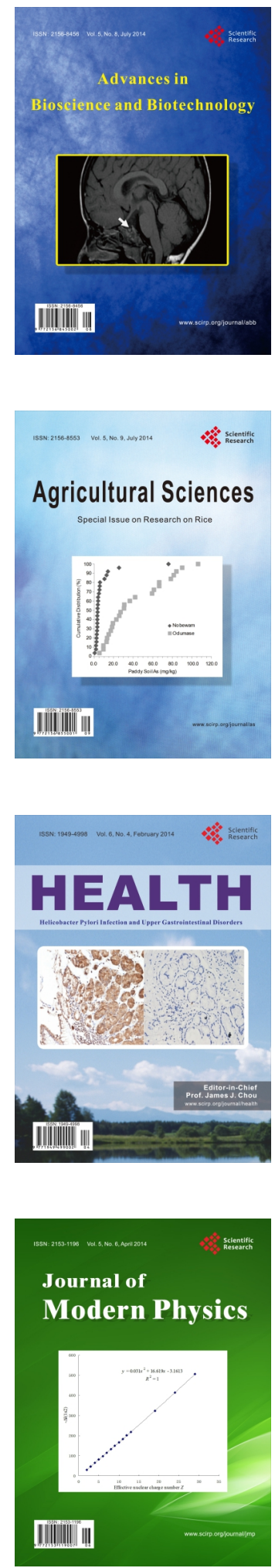
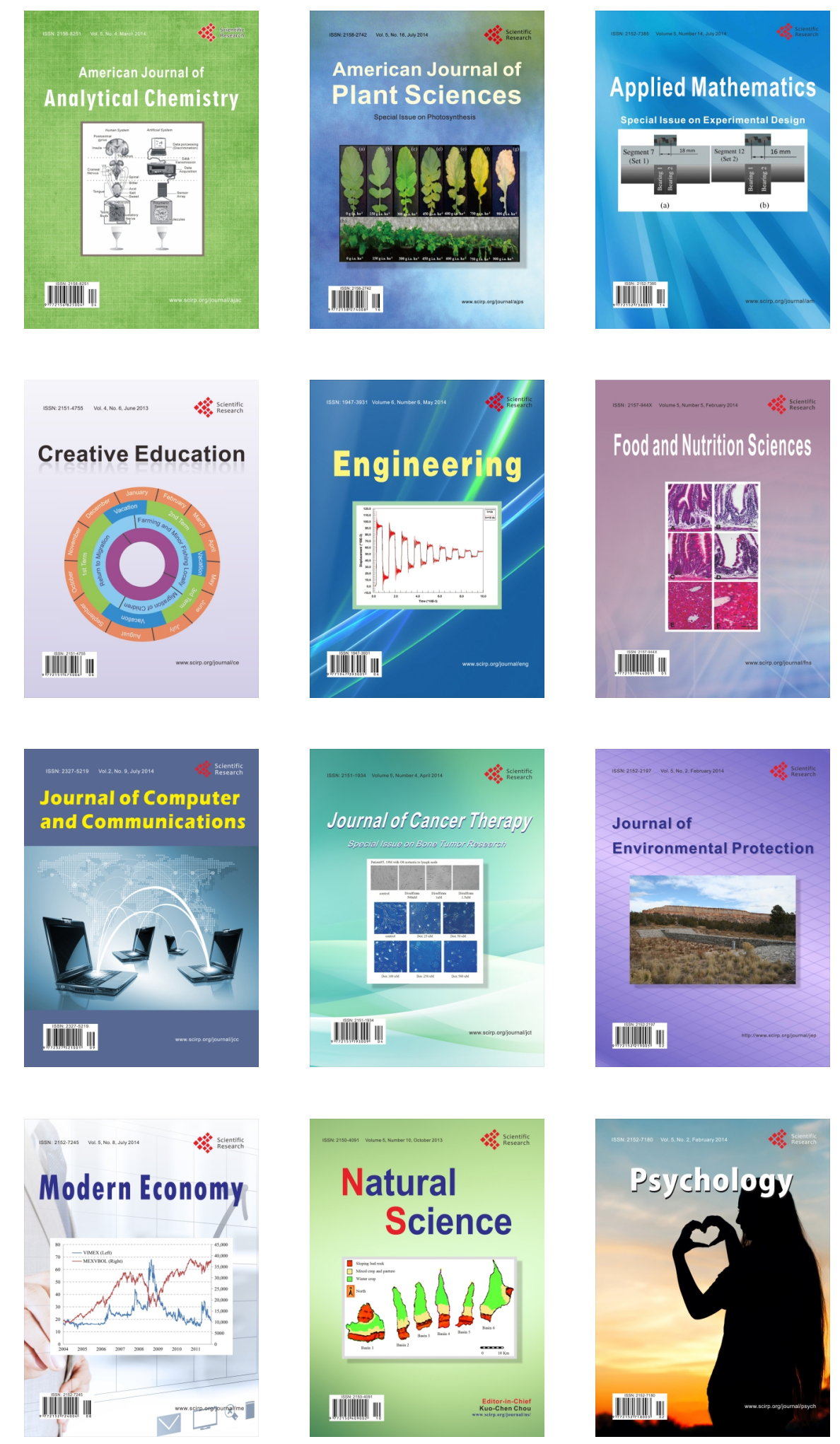